\title{
Progress in animal experimentation ethics. A case study from a brazilian medical school and from the international medical literature ${ }^{1}$
}

\author{
Progresso na ética em experimentação animal. O estudo de caso de uma escola médica \\ brasileira e da literatura médica internacional
}

\author{
Edvaldo Luiz Ramalli Jr.I, Wanli Ho', Mônica Alves"I, Eduardo Melani Rocha ${ }^{I I I}$ \\ IGraduate student, Faculty of Medicine of Ribeirao Preto, USP, Sao Paulo, Brazil. Data collection, literature research and manuscript writing. \\ "PhD, Associate Professor, Faculty of Medicine, Pontific Catholic University of Campinas, Postdoctoral, Faculty of Medicine of Ribeirao Preto, USP, \\ Sao Paulo, Brazil. Manuscript writing, critical revision and final approval. \\ IIIPhD, Associate Professor, Faculty of Medicine of Ribeirao Preto, USP, Sao Paulo, Brazil. Supervised all phases, conception, design, intellectual and \\ scientific content of the study, critical revision.
}

\begin{abstract}
PURPOSE: This study describes in Brazil and in the global biomedical community the time course of the development of animal research welfare guidelines.

METHODS: The database of the Ethics Committee of the Faculty of Medicine of Ribeirao Preto (EC/FMRP-USP), Brazil, was surveyed since its inception in 2002 as the regulations became more stringent to provide better protection of animal research welfare at this institution. Medline database was evaluated to identify the number of publications in the period between 1968 and 2008 that used research animals and were in compliance with established ethics guidelines.

RESULTS: The EC/FMRP-USP evaluated 979 projects up until 2009. Most of the applications came from Department of Physiology and the most frequently requested species was the rat. In 2004, national research funding agencies started to request prior approval from institutional review ethics committees prior to application review and this requirement became federal law in Brazil in 2008 . The analysis of international publications revealed a relative reduction in studies involving research animals (18\% in 1968 to $7.5 \%$ in 2008$)$. CONCLUSIONS: The present work showed that in the last four decades major changes occurred in the guidelines dictating use of research animals occurred and they are being adopted by developing countries. Moreover, animal welfare concern in the scientific community preceded the introduction of journal guidelines for this purpose. Furthermore, in Brazil it was anticipated that laws were needed to protect animal research welfare from being not upheld.
\end{abstract}

Key words: Ethics. Animal Experimentation. Database.

\section{RESUMO}

OBJETIVO: Caracterizar a evolução da pesquisa com animais no Brasil e na comunidade biomédica mundial.

MÉTODOS: O banco de dados do Comitê de Ética da Faculdade de Medicina de Ribeirão Preto (CE/FMRP-USP), Brasil, foi analisado desde a sua criação em 2002, bem como a legislação regulatória para pesquisa com animais no país. As publicações do período de 1968 a 2009 do banco de dados Medline foram avaliadas para identificação do uso de animais em pesquisa e da aderência às regulamentações de ética.

RESULTADOS: O CE/FMRP-USP avaliou 979 projetos até 2009, sendo a maioria das solicitações do Departamento de Fisiologia e o rato a espécie mais utilizada. Em 2004, as agências nacionais de incentivo a pesquisa começaram a exigir a aprovação prévia de comitês de ética e este requerimento se tornou Lei Federal no Brasil em 2008. A análise de publicações internacionais revelou uma redução no número de estudo envolvendo pesquisa com animais (18\% em 1968 to 7,5\% em 2008).

CONCLUSÃO: O presente estudo mostrou que, nas últimas décadas, importantes mudanças na regulamentação do uso de animais em pesquisa e estão sendo assimiladas nos países em desenvolvimento. A preocupação com bem estar animal pela comunidade científica precedeu a introdução de regras pelas revistas e, no Brasil, antecipou a regulamentação federal.

Descritores: Ética. Experimentação Animal. Base de Dados. 


\section{Introduction}

For many centuries extending back to a time nearly twelve thousand years that predates written records when agriculture and animal domestication started, animals have been used for research by humans from different cultures. Their usage provided answers to questions pertaining to health and welfare. This historical perspective demonstrates how effective and essential it has been to use animals as test subjects to provide in some cases life-saving answers to numerous biomedical questions. Despite these important advances, extremist organizations have come into existence that are strongly opposed to the continued use of animals for biomedical research in the laboratory. They have launched a "Research Animal War"1-2 whose objective is to prohibit all types of animal research.

In the nineteenth century in the United Kingdom, emerging public concern about the ethical use of animals resulted in the establishment of legal guidelines that defined procedures to be implemented protecting them from being used in an abusive manner. Such concern about the protection of animal welfare rights became important on an international scale as indicated by the passage in 1966 in the USA of the Animal Welfare Act $^{3}$. Indeed, new animal welfare research guidelines are being continuously codified by journals, institutions and research funding agencies requiring researcher compliance before initiating experimental studies. However, the chronology and impact of developing methodological requirements on research endeavors have not been addressed before now ${ }^{4-6}$.

Brazil is among the twenty leading countries in the world whose number of biomedical publications is having a positive impact in different disciplines. The Faculty of Medicine at Ribeirao Preto, Sao Paulo University (FMRP-USP) is a major biomedical research center in Brazil that provides high quality contributions to biomedical research and has received attention for its potential growth due to favorable economic support ${ }^{7-9}$. The local Animal Research Ethical Committee was created in 2002 (http://www.fmrp.usp.br/cetea) $)^{10}$, following guidelines of "Colégio Brasileiro de Experimentação Animal" (COBEA), which recently changed its name to "Sociedade Brasileira de Ciência de Animal de Laboratório", SBCal (http://www.cobea.org.br) ${ }^{11}$. This committee was created six years ahead of the establishment of a Brazilian Animal Welfare Research legal code. Recommendations on how to be in compliance with international guidelines were already published in Brazilian biomedical journals for more than a decade. This was already initiated when it was estimated that only $20 \%$ of the world-wide journals presented specific animal welfare research guidelines in the instructions for authors ${ }^{12}$.

A Brazilian federal law regulating the issues related to animal research was published in October 2008, (http://www. planalto.gov.br/ccivil_03/_Ato2007-2010/2008/Lei/L11794. $\underline{\mathrm{htm}})^{13}$. It repealed a previous one and the first regulating this matter, signed by the Brazilian president in May 08, 1979. At that time, the government regulated the aspects of animal facilities, need for proper housing, anesthesia, euthanasia and technical supervision for animal experimentation, limited the purpose of animal vivisection to research and education (http://www.bioetica. ufrgs.br/lei6638.htm $)^{14}$. In 1998, a federal law determined the limits for using wild animals for any purpose, established the penalties and the governmental offices in charge to enforce it (http://www. planalto.gov.br/ccivil 03/leis/L9605.htm) ${ }^{15}$. However, only the law signed in 2008 determined the creation of institutional committees of ethics in animal experimentation and the National Council of Animal Experimentation Control, formally "Conselho Nacional de Controle de Experimentação Animal" (CONCEA).

Several practical aspects of the mentioned law were detailed in a subsequent decree from July 2009 (http://www. planalto.gov.br/ccivil_03/Ato2007-2010/2009/Decreto/D6899. $\underline{\mathrm{htm}})^{16}$. Among other items it determined the infractions and their penalties and created a register of institutions that use animal in research, formally "Cadastro das Instituições de Uso Científico de Animais" (CIUCA).

Medline is a public database that indexes journal articles pertaining to biomedical research and allows free electronic access to more than 19 million citations citations from 1950 to the present. The core clinical journals, formerly called the Abridged Index Medicus compiles the contents of 121 biomedical journals indexed in PubMed, which was established by the National Library of Medicine in 1970, and can be used as search filter.

This study documents the chronology of the guideline improvements that are being made to be in compliance with animal research ethical standards at a leading Brazilian research institution who is a member of the global biomedical research community. 


\section{Methods}

Animal research Ethical Committee FMRP-USP

The databank of the FMRP-USP Animal Research Ethical Committee was analyzed from its creation in 2002 through the end of 2009. The following data was obtained: number of projects submitted, research area of applicant, animal species requested, length of journal review time needed for rendering a final decision on manuscript acceptability, and the rate of journal rejection.

\section{PubMed search}

A PubMed search of the "Core Clinical Journals"was performed to identify the proportion of biomedical publications, which used research animals (http://www.nlm.nih.gov). The search extended from 1968 to 2008 in ten year intervals ranging from: a) 1968 -1978; b) 1978 to 1988 ; c) 1988 to 1998 ; d) 1998 to 2008 . The 200 first occurrences retrieved, using the following limits: core clinical journals, specific date range extending from January $1^{\text {st }}$ to December 31, with English Abstracts, organized in chronological order from the earliest to the oldest were analyzed. The number of studies with animals and the species indicated were recorded.

\section{Periodicals survey}

The Journal Citation Report database was searched to identify the 20 journals from 2008 with highest impact factor and which published studies with research animals (http://admin-apps. webofknowledge.com). The guidelines for authors in the past 40 years published in those journals were searched to identify the year when a) a recommendation of adherence to the principles of ethics was made; and b) the pre-approval by the ethics committees of educational institutions was made, as a prerequisite for submissions to these journals.

Using the same procedure, published articles in those journals were searched to identify when authors started to mention adherence to institutional or national guidelines for dealing with research animals and whether it proceeded when the editorial requirements were established.

\section{Results}

\section{FMRP-USP animal research Ethical Committee}

Since its inception in 2002 until the end of 2009, the FMRP-USP Animal Research Ethical Committee evaluated 979 projects. The number of projects per year started to increase in 2003, and peaked in 2005 and it has been growing since 2006
(Figure 1).

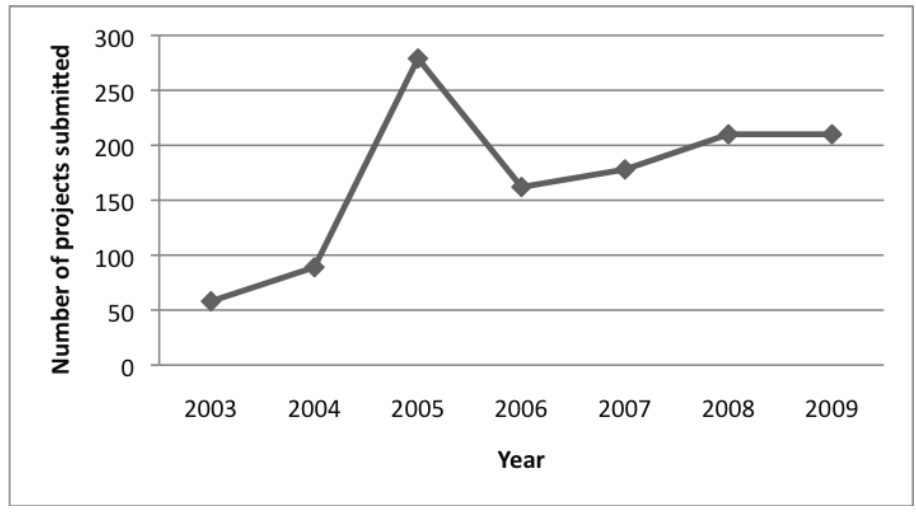

FIGURE 1 - Number of projects per year submitted to the Animal Research Ethical Committee FMRP-USP, between 2002 and 2009. In 2004, major Brazilian funding agencies included the necessity for application approval by an institutional animal research ethical committee, prior to evaluation.

Applications dealing with physiology questions exceeded those in all other areas requesting permission for animal usage (Figure 2).

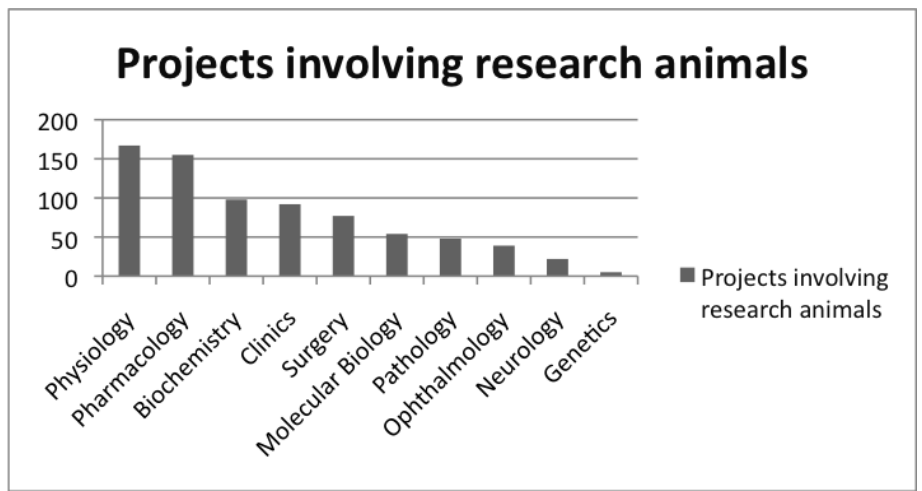

FIGURE 2 - Projects involving use of research animals in different scientific divisions at FMRP-USP between 2002 and 2009.

The most used specie was rat, followed by mice, however several projects mentioned a broad range of animals, as rabbits, bovines, pigs, snakes, goats, lizard, hamsters, embryonated eggs (Figure 3).

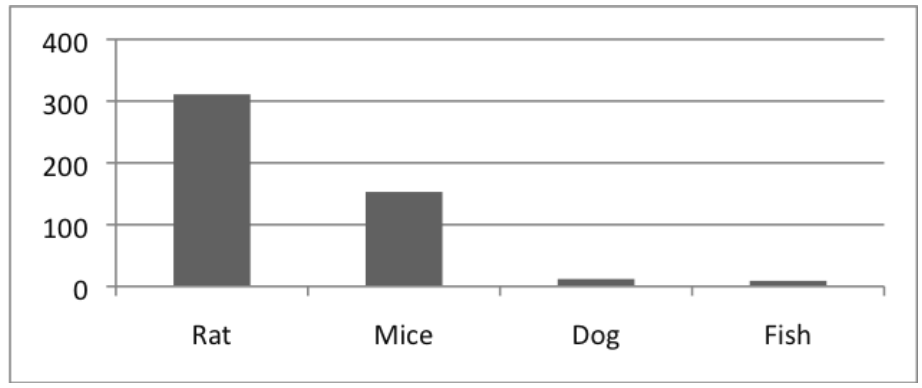

FIGURE 3 - Distribution of animal species in research projects submitted to the FMRP-USP Animal Research Ethical Committee between 2002 and 2009. 
Only one study was performed using primates during this period. The overall mean time between submission and final committee decision was $50.3 \pm 27.4$ days. The refusal rate was 4.3 $\pm 2.3 /$ year.

The time between submission and final decision was 62.8 \pm 43.3 days in 2002 and $57 \pm 32.8$ days in 2009. None of the applications were refused a priori; however, all of those that failed in submit a reply to their evaluation, in the period of 30 days, were filed as refused.

\section{PubMed search}

The PubMed search found an increasing number of publications from core clinical journals in the last 40 years; in 1968 there were 423 publications whereas by 2008 the number had increased to over 35,000 (Table 1).

TABLE 1 - Number of articles published in Clinical Core Journals and proportion of articles involving research animals, as observed in the first 200 inputs.

\begin{tabular}{ccc}
\hline Year & Number of Articles & Articles involving animals \\
\hline $1968^{*}$ & 423 & $18 \%$ \\
1978 & 18228 & $15 \%$ \\
1988 & 28005 & $10 \%$ \\
1998 & 30829 & $4.5 \%$ \\
2008 & 35350 & $7.5 \%$ \\
\hline
\end{tabular}

*Clinical Core Journals was defined in 1970, so 1968 search was performed with journals later listed but being published at 1968 .

However the percentage of studies involving experimental animals decreased over $10 \%$ in 40 years. The incidence of animal usage was lower in each year except in 1998 and 2008 (Table 1).

The frequency of usage of different species revealed a decrease in studies involving bigger animals (e.g.; dog and pig) whereas smaller animals were used more frequently (rodents) (Figure 4).

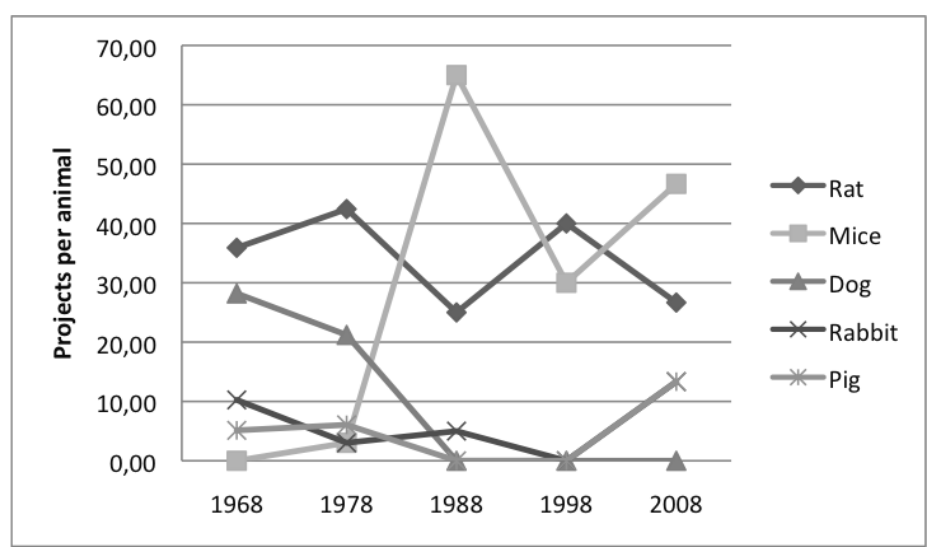

FIGURE 4 - Distribution of animal species usage in article samples between 1968 and 2008.

Periodicals surveyed among the group with the highest impact factor and which included studies involving research animals, revealed that $100 \%$ of the journal article authors were in compliance with authors guidelines that started to appear in 1992. Authors' disclosure compliance with proposed guidelines started earlier. Compliance is first indicated in 1988 in articles within this group of journals. None of the applications were refused $a$ priori; however, all of those that failed in submit a reply to their evaluation, in the period of 30 days, were filed as refused.

\section{Discussion}

We describe here the chronology of the establishment of institutional and publisher animal research welfare guidelines requiring researcher compliance prior to their submission of manuscripts and applications for extramural grant support. This assessment furthermore reveals that international policies generated for animal protection are in part a consequence of the establishment of Brazilian national guidelines and ethical standards of its investigators. These world-wide changes were first instituted in the United Kingdom and Brazilian acceptance of them also pushed some other countries to make them part of their framework protecting animals from being abused ${ }^{3,15}$. A part of this change is also reflected by the trend to predominantly use smaller rodents. Another indicator is that an increasing number of applications have to be approved by in house Institutional Ethical Committee review boards prior to review by external state and national funding agencies.

The effort of ethical committees to guarantee animal welfare and ensure the observation of established guidelines will certainly improve when those committees become able to follow the procedures of housing, manipulation and execution of research projects 
In Brazil, as in many other countries, academic research is predominantly sponsored by government resources, whose constituents are supportive of funds being used for animal research. However such unanimity is not always the case since public support for research involving animals is variable from 24 to $45 \%$ and can reach $90 \%$. In some instances, public opinion was obtained without providing the justification for the need to use animals to satisfy the specific aims of the research project ${ }^{15,16}$.

The survey of journal articles over the last 40 years revealed a proportional reduction in studies involving animals and a clear preference for rodents, instead of larger animals. This observation is in agreement with trends previously reported, and may reveal the commitment by the scientific community to adhere to the $3 \mathrm{R}$ principle (replacement, reduction, refinement) advocated by Russel and Burch, in The Principles of Human Experimental Technique ${ }^{15}$.

Journals requiring authors to sign a statement that they are in compliance with guidelines established to guarantee animal research welfare is a newly established requirement event. Nevertheless, the proportion of journals that still have no clear policy regarding this issue is still higher than $50 \%{ }^{17}$ and in such cases, authors do not state compliance to any guidelines. It is possible that the requirement by core journals to require authors to provide assurance of adherence to animal research welfare guidelines occurred in response to institutions requiring such a guarantee from investigators prior to obtaining approval for submission of their research applications to external funding agencies. This is tenable since such an institutional requirement was established four years prior to it being instituted by core journals

\section{Conclusions}

The present study showed that in recent decades, there is an increasing concern about establishing animal research welfare guidelines by biomedical research institutions and journal publishers. Meeting this objective involves optimizing efforts by peer research task forces, funding agencies and journal publishers to scrutinize applications and manuscripts for guarantees of adherence to animal research guidelines.

\section{References}

1. Johnston C. Researchers, animals activists fight public relations war at western. CMAJ 1993;148(8):1349-53.

2. Conn PM, Parker JV. The animal research war. Faseb J. 2008;22:1294-5.

3. Rezende A, Peluzio M, Sabarense C. Animal experimentation: ethics and brazilian legislation. Rev Nutr Campinas. 2008;21:23742 .

4. Schnaider TB. Ética e pesquisa. Acta Cir Bras. 2008;23(1):107-11. Available from www.scielo.br/acb.

5. Schanaider A, Silva PC. Uso de animais em cirurgia experimental. Acta Cir Bras. 2004;19(4):441-7. Available from http://www.scielo. br/acb.

6. Pimenta LG, Silva AL. Ética e experimentação animal. Acta Cir Bras. 2001;16(4):255-60. Available from http://www.scielo.br/acb.

7. Regalado A. Science in Brazil, brazilian science riding a gusher. Science. 2010;330(6009):1306-12.

8. Go south, young scientist. The Economist. 2011;6:36-7. Available from http://www.economist.com/node/17851421.

9. Zorzetto R, Razzouk D, Dubugras MT, Gerolin J, Schor N, Guimaraes JA, Mari JJ. The scientific production in heath and biological sciences of the top 20 brazilian universities. Braz J Med Biol Res. 2006;39(12):1513-20.

10. CETEA. Animal Research Ethical Committee. Available from http://www.fmrp.usp.br/cetea.

11. COBEA and "Sociedade Brasileira de Ciência de Animal de Laboratório", SBCal. Available from http://www.cobea.org.br.

12. Goldenberg S. Aspectos éticos da pesquisa com animais. Acta Cir Bras. 2000;15(4):193-5. Available from http://www.scielo.br/acb.

13. Federal Brazilian Law L11794, 2008. Available from http://www. planalto.gov.br/ccivil_03/Ato2007-2010/2008/Lei/L11794.htm.

14. Federal Brazilian Decret D6899, 2009. Available from http://www. planalto.gov.br/ccivil_03/_Ato2007-2010/2009/Decreto/D6899. htm.

15. Festing S, Wilkinson R. The ethics of animal research. Talking point on the use of animals in scientific research. EMBO. 2007;8(6):52630.

16. Animal research is a source of human compassion, not shame. Lancet. 2004;364(9437):815-6.

17. Osborne NJ, Payne D, Newman ML. Journal editorial policies, animal welfare and 3Rs. Am J Bioeth. 2009;8(12):55-9.

\section{Acknowledgements}

To the contribution of Gustavo Zanin, Ariana de Salvo Arthur, Peter Sol Reinach and Sandra Maria de Cara Galeani.

\section{Correspondence:}

Mônica Alves

Avenida Bandeirantes, 3900

14049-900 São Paulo - SP Brasil

Tel/Fax: (55 16)3602-2523

monicalves@fmrp.usp.br

Received: April 30, 2012

Review: June 29, 2012

Accepted: July 27, 2012

Conflict of interest: none Financial sources: National Council of Technological and Scientific Development $(\mathrm{CNPq})$ and University of Sao Paulo (FAEPA)

${ }^{1}$ Research performed at Department of Ophthalmology, Otorhinolaryngology and Head and Neck Surgery, Faculty of Medicine Ribeirao Preto, University of Sao Paulo, Brazil. 